\title{
A Tris(diisocyanide)chromium(0) Complex Is a Luminescent Analog of $\mathrm{Fe}\left(2,2^{\prime} \text {-Bipyridine }\right)_{3}{ }^{2+}$
}

\author{
Laura A. Büldt, Xingwei Guo, Raphael Vogel, Alessandro Prescimone, and Oliver S. Wenger*(i) \\ Department of Chemistry, University of Basel, St. Johanns-Ring 19 and Spitalstrasse 51, 4056 Basel, Switzerland
}

Supporting Information

ABSTRACT: A meta-terphenyl unit was substituted with an isocyanide group on each of its two terminal aryls to afford a bidentate chelating ligand $\left(\mathrm{CN}^{\mathrm{t} B u} \mathrm{Ar}_{3} \mathrm{NC}\right)$ that is able to stabilize chromium in its zerovalent oxidation state. The homoleptic $\mathrm{Cr}\left(\mathrm{CN}^{\mathrm{tBu}} \mathrm{Ar}_{3} \mathrm{NC}\right)_{3}$ complex luminesces in solution at room temperature, and its excited-state lifetime $(2.2 \mathrm{~ns}$ in deaerated THF at $20{ }^{\circ} \mathrm{C}$ ) is nearly 2 orders of magnitude longer than the current record lifetime for isoelectronic $\mathrm{Fe}$ (II) complexes, which are of significant interest as earth-abundant sensitizers in dye-sensitized solar cells. Due to its chelating ligands, $\mathrm{Cr}\left(\mathrm{CN}^{\mathrm{tBu}} \mathrm{Ar}_{3} \mathrm{NC}\right)_{3}$ is more robust than $\mathrm{Cr}(0)$ complexes with carbonyl or monodentate isocyanides, manifesting in comparatively slow photodegradation. In the presence of excess anthracene in solution, efficient energy transfer and subsequent triplet-triplet annihilation upconversion is observed. With an excited-state oxidation potential of $-2.43 \mathrm{~V}$ vs $\mathrm{Fc}^{+} / \mathrm{Fc}$, the $\mathrm{Cr}(0)$ complex is a very strong photoreductant. The findings presented herein are relevant for replacement of precious metals in dye-sensitized solar cells and in luminescent devices by earth-abundant elements.

\section{INTRODUCTION}

Complexes of precious $\mathrm{d}^{6}$ metals such as $\mathrm{Ru}(\mathrm{II}), \mathrm{Ir}(\mathrm{III}), \mathrm{Os}(\mathrm{II})$, or $\operatorname{Re}(\mathrm{I})$ are very popular because they exhibit long-lived, redox-active excited states when equipped with suitable ligands. They are used, for example, as luminophores in light emitting devices, ${ }^{1}$ as dyes in solar and photoelectrochemical cells, ${ }^{2}$ as sensitizers of photoredox reactions in organic chemistry, ${ }^{3}$ or as photosensitizers for the production of solar fuels. ${ }^{4}$ There is a long-standing interest in replacing these precious metals by more earth-abundant elements, ${ }^{5}$ but this is difficult because nonradiative relaxation processes tend to deactivate the excited states of first-row transition metals very efficiently. $\mathrm{Cu}(\mathrm{I})$ complexes are an interesting alternative, which has been explored in considerable depth, ${ }^{6}$ and a less common example is $\mathrm{Cr}(\mathrm{III}) .^{7}$ Recently, important progress on the photophysics of $\mathrm{Fe}$ (II) complexes has been made. Excited-state deactivation channels were unraveled in unprecedented detail, ${ }^{8}$ and new guiding principles for the design of ligands have emerged, ${ }^{9}$ in some cases leading to record excited-state lifetimes (up to 37 ps) for $\mathrm{Fe}(\mathrm{II})$ complexes. ${ }^{10}$ Many of these studies were motivated by the idea to replace ruthenium in dye-sensitized solar cells by iron complexes.

$\mathrm{Cr}(0)$ is isoelectronic with $\mathrm{Fe}(\mathrm{II})$, and it seemed worthwhile to explore the possibility of obtaining homoleptic $\operatorname{Cr}(0)$ complexes with long-lived emissive excited states, particularly in view of known luminescent $\mathrm{Mo}(0)$ and $\mathrm{W}(0)$ isocyanides. ${ }^{11}$ $\mathrm{Cr}(0)$ isocyanide complexes can undergo photoinduced ligand dissociation similar to $\mathrm{Cr}(0)$ carbonyl compounds, ${ }^{12}$ but an
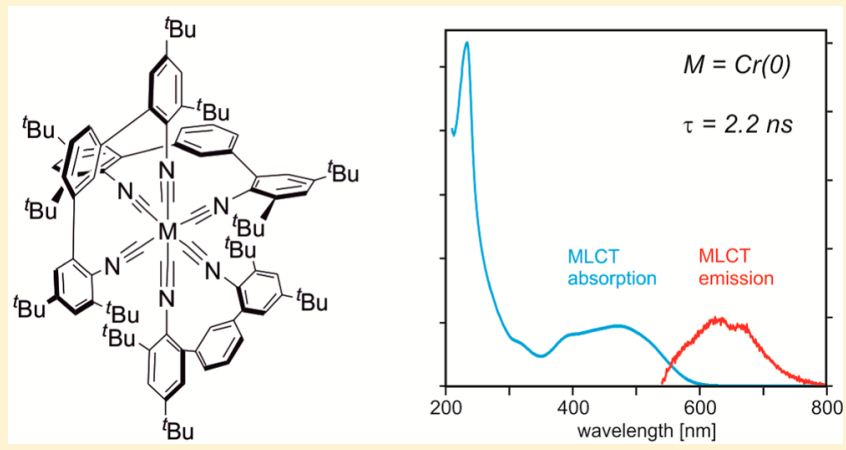

early study reported on low-temperature $(77 \mathrm{~K})$ emission of a homoleptic hexakis(isocyanide) complex of $\mathrm{Cr}(0) .{ }^{11 \text { a }}$ Against this background, we focused on chelating diisocyanides with the rationale that such ligands could potentially give access to more robust $\mathrm{Cr}(0)$ complexes than monodentate isocyanides, which could even exhibit long-lived emissive excited states at room temperature in solution.

There has been relatively little prior work on the photophysics of metal complexes with chelating isocyanides, ${ }^{14}$ but recently we communicated that a homoleptic $\mathrm{Mo}(0)$ complex with a bidentate diisocyanide (Scheme 1a) exhibits very favorable optical spectroscopic and electrochemical properties. ${ }^{13}$ For the present study, we prepared a new ligand in which the metal center is well shielded from the chemical environment through sterically demanding substituents, anticipating that this would increase robustness and chances of obtaining room temperature emission in a $\mathrm{Cr}(0)$ complex. The strategy of using bulky monodentate isocyanides has been very useful for stabilizing other metals in low oxidation states. ${ }^{15}$ In the case of our bidentate diisocyanides, this design principle gives access to a homoleptic $\mathrm{Cr}(0)$ complex (Scheme $1 \mathrm{~b}$ ) that exhibits luminescence in deaerated THF at $20{ }^{\circ} \mathrm{C}$. The excited-state lifetime under these conditions is $2.2 \pm 0.4 \mathrm{~ns}$, nearly 2 orders of magnitude longer than the recently reported record lifetime of $\mathrm{Fe}(\mathrm{II})$ complexes in solution. ${ }^{10}$

Received: November 15, 2016

Published: January 5, 2017 
Scheme 1. Molecular Structures of (a) $\mathrm{Mo}\left(\mathrm{CNAr}_{3} \mathrm{NC}\right)_{3}$ (from Ref 13) and (b) $\mathrm{Cr}\left(\mathrm{CN}^{\mathrm{tBu}} \mathrm{Ar}_{3} \mathrm{NC}\right)_{3}$ (This Work)
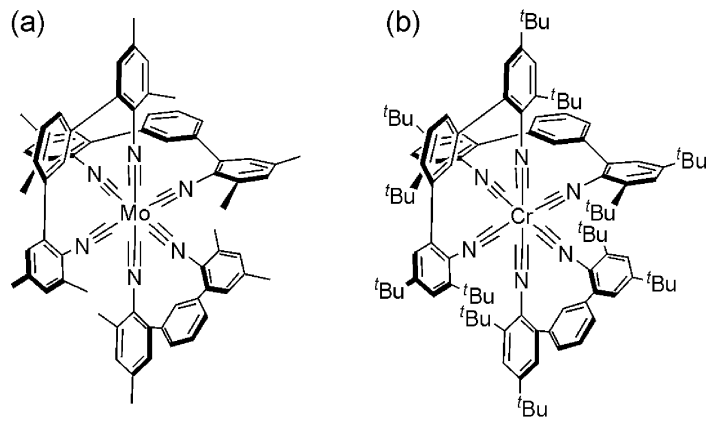

RESULTS AND DISCUSSION

Synthesis, X-ray Crystal Structure, Infrared Spectroscopy, and Cyclic Voltammetry. Ligand synthesis (Scheme 2) started with nitration of commercial 3,5-di(tert-butyl)bromobenzene (1) followed by Suzuki-Miyura coupling of the nitrobenzene product (2) with a diboronic ester derivative of 1,3-bromobenzene (3). After reduction of the coupling product (4) to the dianiline (5), formylation with $\mathrm{HCOOH}$ and subsequent reaction of the diformamide (6) with $\mathrm{POCl}_{3}$ afforded the final ligand $\left(\mathrm{CN}^{\mathrm{tBu}} \mathrm{Ar}_{3} \mathrm{NC}\right)$. The $\mathrm{Cr}(0)$ complex was obtained by preparing $\mathrm{CrCl}_{3}$ (THF) ${ }_{3}$ from $\mathrm{CrCl}_{3},{ }^{14 \mathrm{~b}}$ and by reacting the precursor complex with $\mathrm{CN}^{\mathrm{tBu}} \mathrm{Ar}_{3} \mathrm{NC}$ ligand over $\mathrm{Na} / \mathrm{Hg}$ in dry THF at room temperature. Synthesis procedures and product characterization data are in the Supporting Information (SI).

X-ray diffraction at a single crystal of $\mathrm{Cr}\left(\mathrm{CN}^{\mathrm{tBu}} \mathrm{Ar}_{3} \mathrm{NC}\right)_{3}$ resulted in the structure shown in Figure $1 \mathrm{~b}$. The space-filling representation is used to visualize the fact that the metal center is well shielded from the chemical environment by the sterically demanding $\mathrm{CN}^{\mathrm{tBu}} \mathrm{Ar}_{3} \mathrm{NC}$ ligand. For comparison, our previously published structure of a homoleptic $\mathrm{Mo}(0)$ complex (a)

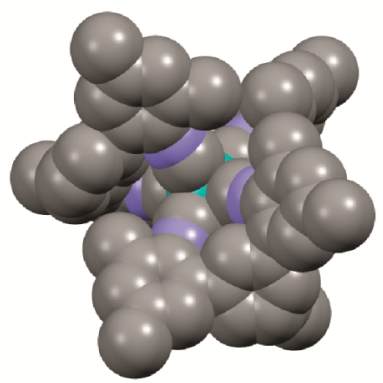

(b)

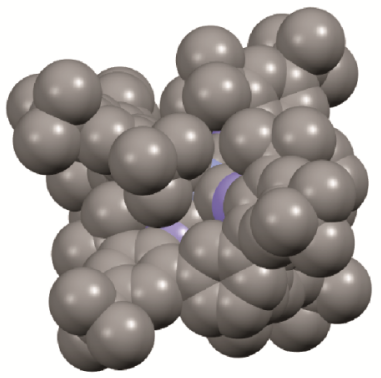

Figure 1. Space filling representations of X-ray crystal structures of (a) $\mathrm{Mo}\left(\mathrm{CNAr}_{3} \mathrm{NC}\right)_{3}$ (from ref 13) and (b) $\mathrm{Cr}\left(\mathrm{CN}^{\mathrm{tBu}} \mathrm{Ar}_{3} \mathrm{NC}\right)_{3}$ (this work). The metal center (turquoise) is visible in the case of the $\mathrm{Mo}(0)$ complex with the sterically less demanding ligand, but it is invisible in the $\mathrm{Cr}(0)$ complex with the new, sterically more demanding ligand. $\mathrm{H}$ atoms have been omitted.

with chelating diisocyanide ligands bearing methyl instead of tert-butyl substituents, $\mathrm{Mo}\left(\mathrm{CNAr}_{3} \mathrm{NC}\right)_{3}$, is shown in Figure 1a. The shielding of the metal center seen in Figure 1 seems to be of key importance for the photophysical studies reported below. $\mathrm{Cr}-\mathrm{C}$ distances and $\mathrm{C}-\mathrm{Cr}-\mathrm{C}$ bond angles are similar to those observed in prior X-ray studies of hexakis(arylisocyanide)chromium $(0)$ complexes. $^{16}$

The $\mathrm{C} \equiv \mathrm{N}$ stretch frequency in the free $\mathrm{CN}^{\mathrm{tBu}} \mathrm{Ar}_{3} \mathrm{CN}$ ligand is $2112 \mathrm{~cm}^{-1}$ (SI, Figure S1), and in the $\mathrm{Cr}\left(\mathrm{CN}^{\mathrm{tBu}} \mathrm{Ar}_{3} \mathrm{NC}\right)_{3}$ complex, it reduces to $1954 \mathrm{~cm}^{-1}$ due to $\pi$-backbonding. This is a common observation for $\mathrm{Cr}(0)$ carbonyl and isocyanide complexes. $^{17}$

Three quasi-reversible waves appear in the cyclic voltammogram of $\mathrm{Cr}\left(\mathrm{CN}^{\mathrm{tBu}} \mathrm{Ar}_{3} \mathrm{NC}\right)_{3}$ recorded in $\mathrm{THF}$ with $0.1 \mathrm{M}$ $\mathrm{TBAPF}_{6}$ (Figure 2a). These waves correspond to the $\mathrm{Cr}(\mathrm{I} / 0)$, $\mathrm{Cr}(\mathrm{II} / \mathrm{I})$, and $\mathrm{Cr}(\mathrm{III} / \mathrm{II})$ couples, in analogy to hexakis(arylisocyanide)chromium $(0)$ complexes. ${ }^{18}$ However, compared to

Scheme 2. Synthesis of the Chelating Diisocyanide Ligand $\mathrm{CN}^{\mathrm{tBu}} \mathrm{Ar}_{3} \mathrm{NC}^{a}$

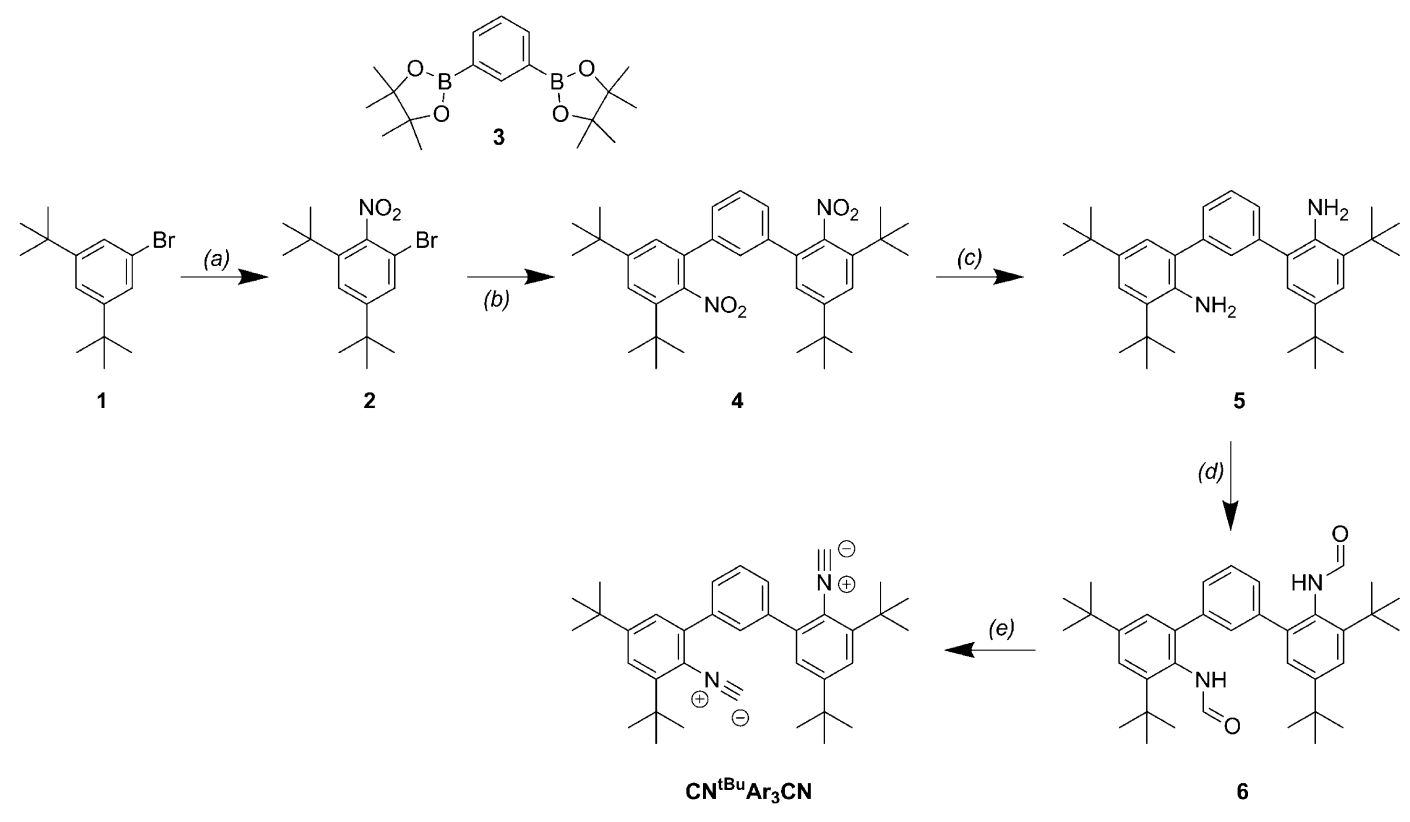

${ }^{a}$ Reagents and conditions: (a) $\mathrm{CH}_{3} \mathrm{COOH}, \mathrm{H}_{2} \mathrm{SO}_{4}$, fuming $\mathrm{HNO}_{3}, 80{ }^{\circ} \mathrm{C}$; (b) $\mathrm{PdCl}_{2}$ (dppf), dioxane, $\mathrm{H}_{2} \mathrm{O}$, reflux; (c) $\mathrm{N}_{2} \mathrm{H}_{4}, \mathrm{Zn}, \mathrm{CH}_{3} \mathrm{OH}$, reflux; (d) $\mathrm{HCOOH}$, acetic anhydride, $100{ }^{\circ} \mathrm{C}$; (e) $\mathrm{POCl}_{3}$, diisopropylamine. 
(a)

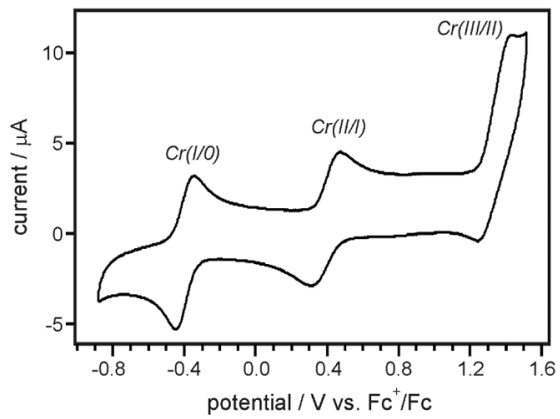

(b)

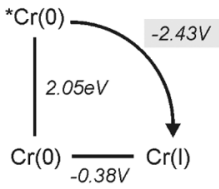

Figure 2. (a) Cyclic voltammogram of $\mathrm{Cr}\left(\mathrm{CN}^{\mathrm{tBu}} \mathrm{Ar}_{3} \mathrm{NC}\right)_{3}$ in THF with $0.1 \mathrm{M} \mathrm{TBAPF}_{6}$ at $20^{\circ} \mathrm{C}$. The potential scan rate was $0.1 \mathrm{~V} / \mathrm{s}$. (b) Latimer diagram for $\mathrm{Cr}\left(\mathrm{CN}^{\mathrm{tBu}} \mathrm{Ar}_{3} \mathrm{NC}\right)_{3}$ used for estimation of the oxidation potential of the emissive ${ }^{3} \mathrm{MLCT}$ excited state.

$\mathrm{Cr}(0)$ complexes with monodentate aryl-isocyanides, the redox potentials of $\mathrm{Cr}\left(\mathrm{CN}^{\mathrm{tBu}} \mathrm{Ar}_{3} \mathrm{NC}\right)_{3}$ are shifted anodically (Table $1)$, for example, by ca. $0.4 \mathrm{~V}$ in the case of the $\mathrm{Cr}(\mathrm{I} / 0)$ couple.

Table 1. Electrochemical Potentials (in $\mathrm{V}$ vs. $\mathrm{Fc}^{+} / \mathrm{Fc}$ )

$\begin{array}{lccc} & \mathrm{Cr}(\mathrm{I} / 0) & \mathrm{Cr}(\mathrm{II} / \mathrm{I}) & \mathrm{Cr}(\mathrm{III} / \mathrm{II}) \\ \mathrm{Cr}\left(\mathrm{CN}^{\mathrm{tBu}} \mathrm{Ar}_{3} \mathrm{NC}\right)_{3}{ }^{a} & -0.38 & 0.40 & 1.33 \\ \mathrm{Cr}\left(\mathrm{CN}-\mathrm{C}_{6} \mathrm{H}_{5}\right)_{6}{ }^{a} & -0.67 & -0.05 & 0.73 \\ \mathrm{Cr}\left(\mathrm{CN}^{2,6-\mathrm{P}^{\mathrm{Pr}}} \mathrm{C}_{6} \mathrm{H}_{5}\right)_{6}{ }^{b} & -0.78 & 0.16 & 1.27\end{array}$

${ }^{a}$ This work, measured in THF with 0.1 $\mathrm{M} \mathrm{TBAPF}_{6}$ (Figure 2). ${ }^{b}$ From ref 19 , measured in $\mathrm{CH}_{2} \mathrm{Cl}_{2}$ with $\mathrm{TBAPF}_{6}$.

This could either reflect a stabilization of the lower oxidation states or a destabilization of the higher oxidation states in the $\mathrm{Cr}\left(\mathrm{CN}^{\mathrm{tBu}} \mathrm{Ar}_{3} \mathrm{NC}\right)_{3}$ complex. ${ }^{19}$ It seems plausible that the latter effect plays a significant role, because the bite angle of the chelating $\mathrm{CN}^{\mathrm{tBu}} \mathrm{Ar}_{3} \mathrm{NC}$ ligand is expected to become more unfavorable with increasing oxidation state as a result of decreasing $\mathrm{Cr}-\mathrm{C}$ bond distances.

Optical Spectroscopy. Dilute solutions of the Cr$\left(\mathrm{CN}^{\mathrm{tBu}} \mathrm{Ar}_{3} \mathrm{NC}\right)_{3}$ complex are orange-red due to the presence of MLCT absorptions between 400 and $600 \mathrm{~nm}$ (black trace in Figure 3a). ${ }^{11,20}$ At shorter wavelengths, ligand-centered $\pi-\pi^{*}$ transitions appear. The UV-vis absorption spectrum of the previously investigated $\mathrm{Mo}\left(\mathrm{CNAr}_{3} \mathrm{NC}\right)_{3}$ complex is similar (black trace in Figure 3c), ${ }^{14}$ but with a somewhat blue-shifted MLCT absorption band. The overall appearance of the absorption spectra in Figure 3a,c is reminiscent of those of the isoelectronic complexes $\mathrm{Fe}(\mathrm{bpy})_{3}{ }^{2+}$ and $\mathrm{Ru}(\mathrm{bpy})_{3}{ }^{2+}$. Following excitation at $500 \mathrm{~nm}$, luminescence from the $\operatorname{Cr}(0)$ complex is observed in deaerated THF solution at room temperature (red trace in Figure 3a), somewhat red-shifted with regard to the emission detected from the $\mathrm{Mo}\left(\mathrm{CNAr}_{3} \mathrm{NC}\right)_{3}$ complex (red trace in Figure 3c). ${ }^{21}$ Slight blue-shifts of the luminescence band maxima are observed when changing from THF to toluene and $n$-hexane (SI, Figure S3), compatible with MLCT emission in both complexes.

Following pulsed excitation at $532 \mathrm{~nm}$, similar transient difference spectra are obtained for the excited states of $\mathrm{Cr}\left(\mathrm{CN}^{\mathrm{tBu}} \mathrm{Ar}_{3} \mathrm{NC}\right)_{3}$ and $\mathrm{Mo}\left(\mathrm{CNAr}_{3} \mathrm{NC}\right)_{3}$ (green traces in Figure $3 \mathrm{~b}, \mathrm{~d})$, but with higher signal-to-noise ratio for the latter due to a longer excited-state lifetime (see below). The main observation in both cases is a bleach of the MLCT absorption between 400 and $600 \mathrm{~nm}$. In the case of the $\mathrm{Mo}(0)$ complex, the somewhat better data quality permits detection of a positive signal around $350 \mathrm{~nm}$ (green trace in Figure 3d), which is tentatively attributed to a $\pi-\pi^{*}$ transition on the reduced
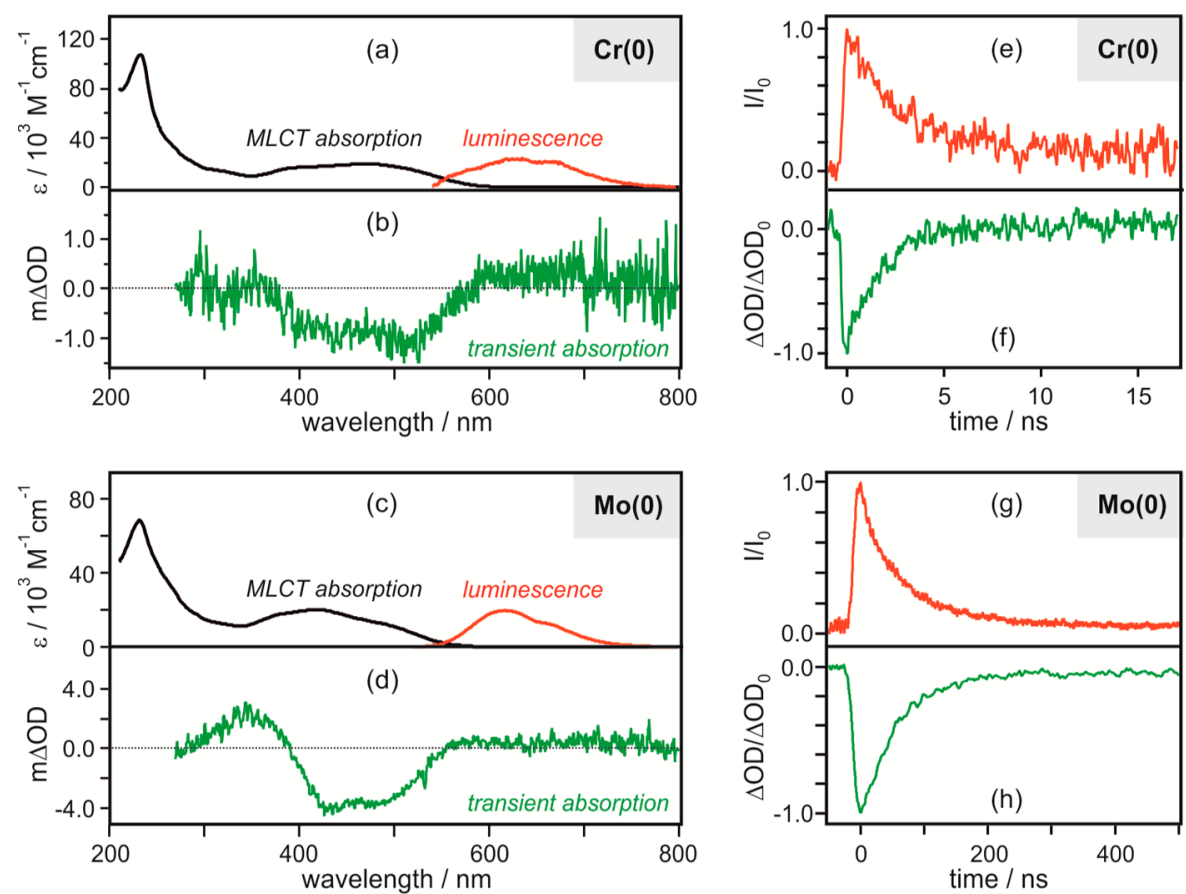

Figure 3. UV-vis absorption (black traces), luminescence (red traces), and transient absorption data (green traces) for $\mathrm{Cr}\left(\mathrm{CN}^{\mathrm{tBu}} \mathrm{Ar}_{3} \mathrm{NC}\right)_{3}$ (upper half) and $\mathrm{Mo}\left(\mathrm{CNAr}_{3} \mathrm{NC}\right)_{3}(\text { lower half })^{13}$ in deaerated THF at $20^{\circ} \mathrm{C}$. Excitation of the steady-state luminescence occurred at $450 \mathrm{~nm}(\mathrm{Cr})$ and at $500 \mathrm{~nm}(\mathrm{Mo})$. For transient absorption studies, excitation occurred at $532 \mathrm{~nm}$ using pulses of $\sim 30 \mathrm{ps}$ duration $(\mathrm{Cr})$ or $\sim 10 \mathrm{~ns}$ duration (Mo). The luminescence decays in panels e and g were detected at 630 and $615 \mathrm{~nm}$, respectively. Detection of the MLCT bleach recoveries in panels $\mathrm{f}$ and $\mathrm{h}$ occurred at 485 and $420 \mathrm{~nm}$, respectively. 

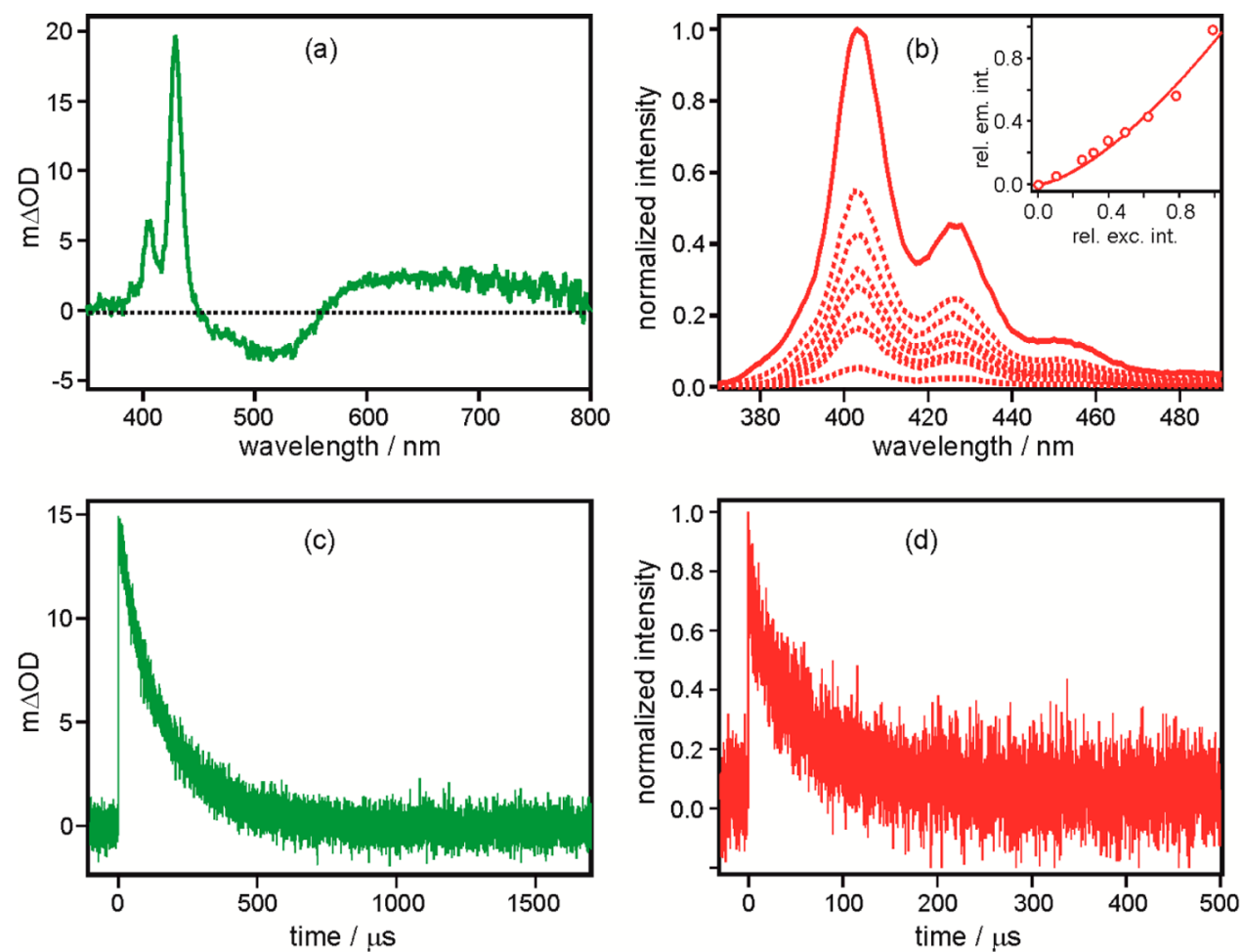

Figure 4. (a) Transient absorption spectrum recorded from a deaerated toluene solution containing $20 \mu \mathrm{M} \mathrm{Cr}\left(\mathrm{CN}^{\mathrm{tBu}} \mathrm{Ar}_{3} \mathrm{NC}\right)_{3}$ and $10 \mathrm{mM}$ anthracene at $20^{\circ} \mathrm{C}$. Excitation was at $532 \mathrm{~nm}$ with pulses of $\sim 10 \mathrm{~ns}$ duration; detection occurred by time-averaging over $200 \mathrm{~ns}$ immediately after excitation. (b) Upconversion luminescence observed from the same solution in the course of steady-state photoexcitation at $530 \mathrm{~nm}$. Inset, dependence of the relative upconversion luminescence intensity at $405 \mathrm{~nm}$ on the relative excitation intensity at $530 \mathrm{~nm}$. (c) Decay of the transient absorption signal from panel a at $430 \mathrm{~nm}$. (d) Decay of the upconversion luminescence intensity from panel b at $405 \mathrm{~nm}$ following excitation at 532 nm with laser pulses of $\sim 10$ ns duration.

ligand, analogous to the transient absorption spectrum of ${ }^{3}$ MLCT-excited $\mathrm{Ru}(\mathrm{bpy})_{3}{ }^{2+} \cdot{ }^{22}$

The luminescence of $\mathrm{Cr}\left(\mathrm{CN}^{\mathrm{tBu}} \mathrm{Ar}_{3} \mathrm{NC}\right)_{3}$ at $630 \mathrm{~nm}$ decays with a time constant of $2.2 \pm 0.4 \mathrm{~ns}$ in deaerated THF at $20{ }^{\circ} \mathrm{C}$ (red trace in Figure 3e), and the MLCT bleach at $485 \mathrm{~nm}$ recovers with an identical time constant (green trace in Figure 3f), following excitation at $532 \mathrm{~nm}$ with pulses of $30 \mathrm{ps}$ duration. This clearly shows that the observed emission does indeed result from the $\mathrm{Cr}\left(\mathrm{CN}^{\mathrm{tBu}} \mathrm{Ar}_{3} \mathrm{NC}\right)_{3}$ complex and not from a luminescent impurity. Analogous time-resolved luminescence and bleach recovery data for the Mo$\left(\mathrm{CNAr}_{3} \mathrm{NC}\right)_{3}$ complex (Figure $3 \mathrm{~g}, \mathrm{~h}$ ) indicate that the excitedstate lifetime in this case is $74 \pm 7 \mathrm{~ns}$ under identical conditions, as reported earlier. ${ }^{13}$

The luminescence quantum yield $(\phi)$ of $\mathrm{Cr}\left(\mathrm{CN}^{\mathrm{tBu}} \mathrm{Ar}_{3} \mathrm{NC}\right)_{3}$ in deaerated THF at $20{ }^{\circ} \mathrm{C}$ is $\sim 10^{-5}$ whereas for Mo$\left(\mathrm{CNAr}_{3} \mathrm{NC}\right)_{3}$ we found $\phi=6 \times 10^{-3}$ under identical conditions. ${ }^{13}$ The significant differences in luminescence quantum yields and excited state lifetimes are attributed to the weaker ligand field in the $\operatorname{Cr}(0)$ complex, leading to efficient nonradiative depopulation via metal-centered $\mathrm{d}-\mathrm{d}$ states (see below). ${ }^{8 \mathrm{a}, \mathrm{c}, 9 \mathrm{~b}, 23}$

In deaerated toluene and $n$-hexane, biexponential excitedstate decays are obtained for $\mathrm{Cr}\left(\mathrm{CN}^{\mathrm{tBu}} \mathrm{Ar}_{3} \mathrm{NC}\right)_{3}$ (SI, Figure S5), unlike in $\mathrm{Mo}\left(\mathrm{CNAr}_{3} \mathrm{NC}\right)_{3}$ where the decays remain singleexponential (SI, Table S2). ${ }^{13}$ The excited-state decay times for $\mathrm{Cr}\left(\mathrm{CN}^{\mathrm{tBu}} \mathrm{Ar}_{3} \mathrm{NC}\right)_{3}$ are $0.32 \mathrm{~ns}(80 \%)$ and $3.73 \mathrm{~ns}(20 \%)$ in $n$ hexane, compared to $0.64 \mathrm{~ns}(83 \%)$ and $4.33 \mathrm{~ns}(17 \%)$ in toluene at $20^{\circ} \mathrm{C}$. In the crystal structure of $\mathrm{Cr}\left(\mathrm{CN}^{\mathrm{tBu}} \mathrm{Ar}_{3} \mathrm{NC}\right)_{3}$ (Figure $1 \mathrm{~b}$ ), the three ligands are not equivalent, as seen for example when considering the relative orientations of the central aryls in the three $\mathrm{CN}^{\mathrm{tBu}} \mathrm{Ar}_{3} \mathrm{NC}$ ligands relative to one another (SI, Figure S6). Interconversion between different ring orientations is sterically hindered by the tert-butyl substituents, and thus it is possible that the biexponential decays in $\mathrm{Cr}\left(\mathrm{CN}^{\mathrm{tBu}} \mathrm{Ar}_{3} \mathrm{NC}\right)_{3}$ are a manifestation of two different conformers, which are present in solution and which do not interconvert on the relevant time scale. An alternative explanation could be that within a given conformer, emission occurs from different MLCT excited states in which the electron is localized on nonequivalent ligands. This latter explanation would imply that delocalization of the excited electron over the three ligands occurs on a relatively slow time scale. A prior transient infrared and DFT study of $\mathrm{W}(0)$ isocyanide complexes demonstrated that localization of the excited electron density on different ligands is indeed possible. $^{11 \mathrm{~d}}$

In frozen matrices at $77 \mathrm{~K}$, the luminescence decays of the $\mathrm{Cr}\left(\mathrm{CN}^{\mathrm{tBu}} \mathrm{Ar}_{3} \mathrm{NC}\right)_{3}$ complex are biexponential in all glasses considered (2-methyl-THF, toluene, 2-methylpentane), with time constants ranging from 1.2 to $16.9 \mu \mathrm{s}$ (SI, Figure S7, Table S3). The observation of microsecond lifetimes for $\mathrm{Cr}$ $\left(\mathrm{CN}^{\mathrm{tBu}} \mathrm{Ar}_{3} \mathrm{NC}\right)_{3}$ is in contrast to the prior finding that $\mathrm{Cr}\left(\mathrm{CN}_{-}{ }^{2,6-i \mathrm{Pr}} \mathrm{C}_{6} \mathrm{H}_{5}\right)_{6}$ exhibits a luminescence lifetime in the nanosecond regime $(<10 \mathrm{~ns})$ at $77 \mathrm{~K}$ (in 2-methylpentane), which suggested that the emissive excited state has significant singlet character. ${ }^{11 \mathrm{a}, 24}$ The microsecond decays of $\mathrm{Cr}$ $\left(\mathrm{CN}^{\mathrm{tBu}} \mathrm{Ar}_{3} \mathrm{NC}\right)_{3}$ at $77 \mathrm{~K}$ indicate that this complex emits from a triplet excited state under these conditions, in analogy to $\mathrm{Mo}\left(\mathrm{CNAr}_{3} \mathrm{NC}\right)_{3}{ }^{13}$ 
Photoredox Properties. Based on the $77 \mathrm{~K}$ luminescence spectrum in 2-methyl-THF (SI, Figure S8), an energy of 2.05 $\mathrm{eV}$ can be determined for the emissive ${ }^{3} \mathrm{MLCT}$ excited state of $\mathrm{Cr}\left(\mathrm{CN}^{\mathrm{tBu}} \mathrm{Ar}_{3} \mathrm{NC}\right)_{3}$. Given a potential of $-0.38 \mathrm{~V} \mathrm{vs}^{+} \mathrm{Fc}^{+} / \mathrm{Fc}$ for the $\mathrm{Cr}(\mathrm{I} / 0)$ couple in the electronic ground state (Figure 2a, Table 1), one can estimate a potential of $-2.43 \mathrm{~V} \mathrm{vs} \mathrm{Fc}^{+} / \mathrm{Fc}$ for $\mathrm{Cr}(0)$ oxidation in the emissive ${ }^{3} \mathrm{MLCT}$ excited state (Figure $2 \mathrm{~b})$. Thus, the $\mathrm{Cr}\left(\mathrm{CN}^{\mathrm{tBu}} \mathrm{Ar}_{3} \mathrm{NC}\right)_{3}$ complex is a similarly strong photoreductant as $\mathrm{Mo}\left(\mathrm{CNAr}_{3} \mathrm{NC}\right)_{3}$ and as recently reported $\mathrm{W}(0)$ aryl-isocyanide complexes (SI, Table S4). ${ }^{1 \mathrm{~b}-\mathrm{d}, 13}$ In principle, the $\mathrm{Cr}\left(\mathrm{CN}^{\mathrm{tBu}} \mathrm{Ar}_{3} \mathrm{NC}\right)_{3}$ complex should be amenable to photoredox applications, which are thermodynamically as challenging as that in our earlier report on $\mathrm{Mo}\left(\mathrm{CNAr}_{3} \mathrm{NC}\right)_{3}$, because it is a far stronger photoreductant than $\mathrm{Ru}(\mathrm{bpy})_{3}{ }^{2+}$ or $\operatorname{Ir}(\text { ppy })_{3}{ }^{13}$

As far as possible applications in dye-sensitized solar cells are concerned, the high reducing power of photoexcited $\mathrm{Cr}$ $\left(\mathrm{CN}^{\mathrm{tBu}} \mathrm{Ar}_{3} \mathrm{NC}\right)_{3}$ suggests that semiconductors other than $\mathrm{TiO}_{2}$ could potentially be used to achieve good energy matching between the sensitizer LUMO and the conduction band of the semiconductor.

Photostability. $\mathrm{Cr}(0)$ complexes with monodentate arylisocyanide or carbonyl ligands undergo photosubstitution reactions in various solvents, due to the population of dissociative $\mathrm{d}-\mathrm{d}$ excited states. ${ }^{12,17 \mathrm{~b}, 20,24,25}$ When a $10^{-5} \mathrm{M}$ solution of $\mathrm{Cr}\left(\mathrm{CN}^{\mathrm{tBu}} \mathrm{Ar}_{3} \mathrm{NC}\right)_{3}$ is irradiated in deaerated THF at $455 \mathrm{~nm}(1 \mathrm{~W})$, the MLCT absorption band between 400 and $600 \mathrm{~nm}$ disappears over time (SI, Figure S9a). In the case of $\mathrm{Cr}(\mathrm{CNAr})_{6}$ complexes, the primary photosubstitution product $\mathrm{Cr}(\mathrm{CNAr})_{5}(\mathrm{THF})$ absorbs at $580 \mathrm{~nm},{ }^{12 a}$ but for $\mathrm{Cr}-$ $\left(\mathrm{CN}^{\mathrm{tBu}} \mathrm{Ar}_{3} \mathrm{NC}\right)_{3}$ no such absorption band is detectable. In THF, the absorbance of $\mathrm{Cr}\left(\mathrm{CN}^{\mathrm{tBu}} \mathrm{Ar}_{3} \mathrm{NC}\right)_{3}$ at $450 \mathrm{~nm}$ decreases in a biphasic manner with half-lives of 7.4 and 70.0 min under photoirradiation (SI, Figure S10a), but the degradation products could not be identified. In $n$-hexane, photodegradation is even slower (SI, Figure $9 \mathrm{~b}$ ) with a half-life of $25.5 \mathrm{~min}$ (SI, Figure S10b). The samples contained $\sim 10^{16}$ complexes, and irradiation of solutions with $\mathrm{OD} \approx 0.3$ occurred with an incident flux of $\sim 10^{17}$ photons/s, yet significant degradation only occurred on a minute time scale. Consequently, these experiments (SI, Figures S9 and S10) demonstrate that $\mathrm{Cr}\left(\mathrm{CN}^{\mathrm{tBu}} \mathrm{Ar}_{3} \mathrm{NC}\right)_{3}$ is relatively robust under photoirradiation, at least in weakly or noncoordinating solvents and under deaerated conditions.

Energy Transfer to Anthracene and Triplet-Triplet Annihilation Upconversion. After pulsed excitation of 20 $\mu \mathrm{M} \mathrm{Cr}\left(\mathrm{CN}^{\mathrm{tBu}} \mathrm{Ar}_{3} \mathrm{NC}\right)_{3}$ at $532 \mathrm{~nm}$ in the presence of $10 \mathrm{mM}$ anthracene in deaerated toluene, the transient absorption spectrum in Figure $4 \mathrm{a}$ was recorded. The typical absorptions of the lowest triplet excited state of anthrancene $\left({ }^{3} \mathrm{An}\right)$ are prominent between 390 and $440 \mathrm{~nm}^{26}$ The emission of $\mathrm{Cr}\left(\mathrm{CN}^{\mathrm{tBu}} \mathrm{Ar}_{3} \mathrm{NC}\right)_{3}$ is strongly quenched under these conditions, indicating that its ${ }^{3} \mathrm{MLCT}$ excited state is depopulated efficiently via triplet-triplet energy transfer to anthracene. It is possible that there is some preassociation between the complex and anthracene, but we did not investigate this specific aspect. Given a ${ }^{3} \mathrm{MLCT}$ energy of $2.05 \mathrm{eV}$ (see above) and a ${ }^{3} \mathrm{An}$ energy of $1.85 \mathrm{eV},{ }^{27}$ the driving-force for triplet-triplet energy transfer is $-0.2 \mathrm{eV}$. The ${ }^{3} \mathrm{An}$ state then decays with a lifetime of $170 \pm 5 \mu \mathrm{s}$, as seen from the transient recorded at $430 \mathrm{~nm}$ (Figure 4c).

Following steady-state irradiation of this solution at $530 \mathrm{~nm}$ in a spectrometer, anthracene fluorescence can be detected

(Figure 4b). After pulsed excitation at $532 \mathrm{~nm}$, the fluorescence signal at $405 \mathrm{~nm}$ decays with a time constant of $65 \pm 5 \mu \mathrm{s}$ (Figure $4 \mathrm{~d}$ ), revealing that this is a case of delayed fluorescence, which is compatible with upconversion via triplet-triplet annihilation. $^{28}$ Indeed, the fluorescence signal in Figure $4 \mathrm{~b}$ exhibits a nonlinear dependence on excitation power (inset in Figure 4b), in line with a two-photon upconversion process (see SI for further details). ${ }^{29}$ The broad transient absorption signal extending from 560 to nearly $800 \mathrm{~nm}$ in Figure $4 \mathrm{a}$ is attributed to an excited-state absorption band of the emitting ${ }^{1}$ An state, ${ }^{30}$ and the finding of a decay time of $70 \pm 5 \mu \mathrm{s}$ (SI, Figure S11a), which is within experimental accuracy the same as that of the delayed fluorescence (see above), supports that assignment.

In the transient absorption spectrum from Figure 4a, a bleach of the ${ }^{1}$ MLCT absorption of the $\operatorname{Cr}(0)$ complex is observed, and this bleach recovers with a time constant of $30 \pm 5 \mu \mathrm{s}$ (SI, Figure S11b). Normally, MLCT bleach recovery would be expected to occur with the time constant corresponding to triplet-triplet energy transfer. The observation of a bleach in Figure $4 \mathrm{a}$ and its slow recovery can be explained by repopulation of the MLCT manifold of $\mathrm{Cr}\left(\mathrm{CN}^{\mathrm{tBu}} \mathrm{Ar}_{3} \mathrm{NC}\right)_{3}$ from the ${ }^{1}$ An state, for example, via Förster-type (singletsinglet) energy transfer (SI, Scheme S1). Under the conditions of our experiments, there was no direct evidence for anthracene dimerization as a result of upconversion. ${ }^{31}$

\section{SUMMARY AND CONCLUSIONS}

A chelating diisocyanide ligand with sterically demanding substituents allowed the synthesis of a homoleptic $\operatorname{Cr}(0)$ complex that is emissive in solution at room temperature. The excited-state lifetime $\left(2.2 \pm 0.4 \mathrm{~ns}\right.$ in THF at $\left.20^{\circ} \mathrm{C}\right)$ of this complex is nearly 2 orders of magnitude longer than the current record lifetime for isoelectronic $\mathrm{Fe}(\mathrm{II})$ complexes (37 ps), ${ }^{10}$ and the $\mathrm{Cr}(0)$ complex is remarkably photostable in weakly and noncoordinating solvents. In $\mathrm{Fe}$ (II) polypyridyl complexes, the ligand field is usually sufficiently weak that metal-centered ${ }^{3} \mathrm{~d}-\mathrm{d}$ and ${ }^{5} \mathrm{~d}-\mathrm{d}$ excited states are energetically below the MLCT manifold (Scheme 3a), leading to ultrafast excited-state depopulation via nonradiative relaxation..$^{8-10,32}$ It seems that in the $\mathrm{Cr}\left(\mathrm{CN}^{\mathrm{tBu}} \mathrm{Ar}_{3} \mathrm{NC}\right)_{3}$ complex, the ligand field is substantially stronger, leading to a significant barrier for

Scheme 3. Potential Energy Diagrams with the Key Electronic States Involved in Excited-State Relaxation of $3 \mathrm{~d}^{6}$ Metal Complexes (a) for Fe(II) Polypyridines and (b) for $\mathrm{Cr}\left(\mathrm{CN}^{\mathrm{tBu}} \mathrm{Ar}_{3} \mathrm{NC}\right)_{3}$

(a)

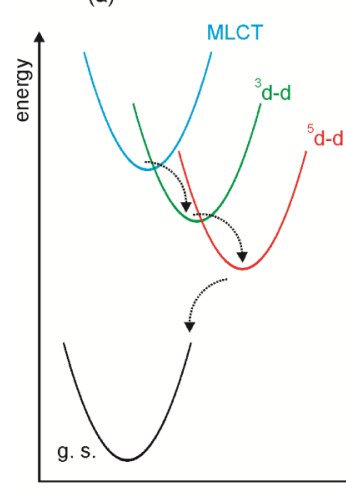

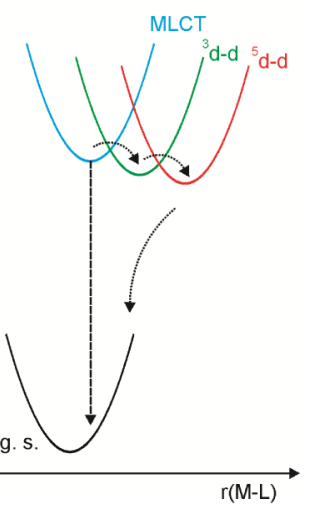


population of the ${ }^{3} \mathrm{~d}-\mathrm{d}$ and ${ }^{5} \mathrm{~d}-\mathrm{d}$ states from the lowest MLCT state (Scheme $3 \mathrm{~b}$ ). As a consequence, luminescence becomes competitive with multiphonon relaxation even at room temperature. The barrier for relaxation into nonemissive ligand field states in $\mathrm{Cr}\left(\mathrm{CN}^{\mathrm{tBu}} \mathrm{Ar}_{3} \mathrm{NC}\right)_{3}$ seems to be even higher than in the recently studied $\mathrm{Fe}$ (II) complexes with $\mathrm{N}$-heterocyclic carbene ligands. $9 \mathrm{c}, 10 \mathrm{~b}$

In first row transition metal complexes, spin-orbit coupling is comparatively weak, and consequently intersystem crossing from ${ }^{1} \mathrm{MLCT}$ to ${ }^{3} \mathrm{MLCT}$ excited states in $\mathrm{Cr}\left(\mathrm{CN}^{\mathrm{tBu}} \mathrm{Ar}_{3} \mathrm{NC}\right)_{3}$ could in principle be relatively slow, even though intersystem crossing rates do not necessarily correlate directly with the magnitude of the spin-orbit coupling constant. ${ }^{33}$ Our energy transfer and triplet-triplet annihilation studies demonstrate that a ${ }^{3} \mathrm{MLCT}$ state is ultimately populated in $\mathrm{Cr}$ $\left(\mathrm{CN}^{\mathrm{tBu}} \mathrm{Ar}_{3} \mathrm{NC}\right)_{3}$. Furthermore, the upconversion studies illustrate the potential of $\mathrm{Cr}(0)$ diisocyanide complexes for photophysical applications.

The luminescence lifetime of $\mathrm{Cr}\left(\mathrm{CN}^{\mathrm{tBu}} \mathrm{Ar}_{3} \mathrm{NC}\right)_{3}$ seems sufficiently long for photoinjection of electrons into semiconductors, particularly in view of recent studies that reported on highly efficient light-to-electron conversion in $\mathrm{TiO}_{2}$-based solar cells sensitized by $\mathrm{Fe}$ (II) complexes with much shorter excited-state lifetimes. ${ }^{9 c, 10 b}$ In conclusion, diisocyanide chelate ligands provide access to robust and emissive $\mathrm{Cr}(0)$ complexes with comparatively long excited-state lifetimes, and our findings are relevant in the context of replacing precious metals in dyesensitized solar cells and luminescent devices by more earthabundant elements.

\section{ASSOCIATED CONTENT}

\section{S Supporting Information}

The Supporting Information is available free of charge on the ACS Publications website at DOI: 10.1021/jacs.6b11803.

Syntheses and product characterization data, X-ray diffraction data, additional optical spectroscopic and electrochemical data (PDF)

Crystallographic structure of $\mathrm{Cr}\left(\mathrm{CN}^{\mathrm{tBu}} \mathrm{Ar}_{3} \mathrm{NC}\right)_{3}$ (CIF)

\section{AUTHOR INFORMATION}

\section{Corresponding Author}

*oliver.wenger@unibas.ch

\section{ORCID ${ }^{\circ}$}

Oliver S. Wenger: 0000-0002-0739-0553

\section{Notes}

The authors declare no competing financial interest.

\section{ACKNOWLEDGMENTS}

This work was funded by the Swiss National Science Foundation through Grant Number 200021_156063/1, through the NCCR Molecular Systems Engineering, and through R'equip Grant Number 206021 157687. Prof. Christian Reber, Dr. Christopher B. Larsen, and Dr. Martin Kuss-Petermann are thanked for valuable discussions.

\section{REFERENCES}

(1) (a) Baldo, M. A.; Thompson, M. E.; Forrest, S. R. Nature 2000, 403, 750. (b) Costa, R. D.; Orti, E.; Bolink, H. J.; Monti, F.; Accorsi, G.; Armaroli, N. Angew. Chem., Int. Ed. 2012, 51, 8178. (c) Yu, T.; Tsang, D. P. K.; Au, V. K. M.; Lam, W. H.; Chan, M. Y.; Yam, V. W. W. Chem. - Eur. J. 2013, 19, 13418.
(2) (a) Hagfeldt, A.; Boschloo, G.; Sun, L. C.; Kloo, L.; Pettersson, H. Chem. Rev. 2010, 110, 6595. (b) Ardo, S.; Meyer, G. J. Chem. Soc. Rev. 2009, 38, 115. (c) Youngblood, W. J.; Lee, S. H. A.; Kobayashi, Y.; Hernandez-Pagan, E. A.; Hoertz, P. G.; Moore, T. A.; Moore, A. L.; Gust, D.; Mallouk, T. E. J. Am. Chem. Soc. 2009, 131, 926.

(3) (a) Canoyelo, H.; Deronzier, A. J. Chem. Soc., Perkin Trans. 2 1984, 1093. (b) Yoon, T. P.; Ischay, M. A.; Du, J. N. Nat. Chem. 2010, 2, 527. (c) Narayanam, J. M. R.; Stephenson, C. R. J. Chem. Soc. Rev. 2011, 40, 102. (d) Prier, C. K.; Rankic, D. A.; MacMillan, D. W. C. Chem. Rev. 2013, 113, 5322. (e) Ghosh, I.; Marzo, L.; Das, A.; Shaikh, R.; König, B. Acc. Chem. Res. 2016, 49, 1566. (f) Huo, H. H.; Shen, X. D.; Wang, C. Y.; Zhang, L. L.; Rose, P.; Chen, L. A.; Harms, K.; Marsch, M.; Hilt, G.; Meggers, E. Nature 2014, 515, 100. (g) Tellis, J. C.; Primer, D. N.; Molander, G. A. Science 2014, 345, 433. (h) Porras, J. A.; Mills, I. N.; Transue, W. J.; Bernhard, S. J. Am. Chem. Soc. 2016, 138, 9460. (i) Tarantino, K. T.; Liu, P.; Knowles, R. R. J. Am. Chem. Soc. 2013, 135, 10022. (j) Bissember, A. C.; Lundgren, R. J.; Creutz, S. E.; Peters, J. C.; Fu, G. C. Angew. Chem., Int. Ed. 2013, 52, 5129. (k) Kerzig, C.; Goez, M. Chem. Sci. 2016, 7, 3862.

(4) (a) Meyer, T. J. Acc. Chem. Res. 1989, 22, 163. (b) Schanze, K. S.; MacQueen, D. B.; Perkins, T. A.; Cabana, L. A. Coord. Chem. Rev. 1993, 122, 63. (c) Lowry, M. S.; Bernhard, S. Chem. - Eur. J. 2006, 12, 7970. (d) Fihri, A.; Artero, V.; Razavet, M.; Baffert, C.; Leibl, W.; Fontecave, M. Angew. Chem., Int. Ed. 2008, 47, 564. (e) Pfeffer, M. G.; Schäfer, B.; Smolentsev, G.; Uhlig, J.; Nazarenko, E.; Guthmüller, J.; Kuhnt, C.; Wachtler, M.; Dietzek, B.; Sundström, V.; Rau, S. Angew. Chem., Int. Ed. 2015, 54, 5044. (f) Dempsey, J. L.; Brunschwig, B. S.; Winkler, J. R.; Gray, H. B. Acc. Chem. Res. 2009, 42, 1995. (g) Boston, D. J.; Xu, C. D.; Armstrong, D. W.; MacDonnell, F. M. J. Am. Chem. Soc. 2013, 135, 16252. (h) Takeda, H.; Ishitani, O. Coord. Chem. Rev. 2010, 254, 346. (i) Kumar, B.; Llorente, M.; Froehlich, J.; Dang, T.; Sathrum, A.; Kubiak, C. P. Annu. Rev. Phys. Chem. 2012, 63, 541. (j) Abrahamsson, M.; Jager, M.; Kumar, R. J.; Osterman, T.; Persson, P.; Becker, H. C.; Johansson, O.; Hammarström, L. J. Am. Chem. Soc. 2008, 130, 15533. (k) Juris, A.; Balzani, V.; Barigelletti, F.; Campagna, S.; Belser, P.; Von Zelewsky, A. Coord. Chem. Rev. 1988, 84, 85. (l) Howarth, A. J.; Majewski, M. B.; Wolf, M. O. Coord. Chem. Rev. 2015, 282, 139. (m) Suneesh, C. V.; Balan, B.; Ozawa, H.; Nakamura, Y.; Katayama, T.; Muramatsu, M.; Nagasawa, Y.; Miyasaka, H.; Sakai, K. Phys. Chem. Chem. Phys. 2014, 16, 1607. (n) Harriman, A.; Hissler, M.; Khatyr, A.; Ziessel, R. Chem. Commun. 1999, 735. (o) McClenaghan, N. D.; Barigelletti, F.; Maubert, B.; Campagna, S. Chem. Commun. 2002, 602. (p) Rodenberg, A.; Orazietti, M.; Probst, B.; Bachmann, C.; Alberto, R.; Baldridge, K. K.; Hamm, P. Inorg. Chem. 2015, 54, 646. (q) Meylemans, H. A.; Hewitt, J. T.; Abdelhaq, M.; Vallett, P. J.; Damrauer, N. H. J. Am. Chem. Soc. 2010, 132, 11464. (r) Klein, J. H.; Sunderland, T. L.; Kaufmann, C.; Holzapfel, M.; Schmiedel, A.; Lambert, C. Phys. Chem. Chem. Phys. 2013, 15, 16024. (s) Windle, C. D.; George, M. W.; Perutz, R. N.; Summers, P. A.; Sun, X. Z.; Whitwood, A. C. Chem. Sci. 2015, 6, 6847. (t) Chen, L. J.; Guo, Z. G.; Wei, X. G.; Gallenkamp, C.; Bonin, J.; Anxolabehere-Mallart, E.; Lau, K. C.; Lau, T. C.; Robert, M. J. Am. Chem. Soc. 2015, 137, 10918. (u) Fedoseeva, M.; Delor, M.; Parker, S. C.; Sazanovich, I. V.; Towrie, M.; Parker, A. W.; Weinstein, J. A. Phys. Chem. Chem. Phys. 2015, 17, 1688.

(5) Gray, H. B.; Maverick, A. W. Science 1981, 214, 1201.

(6) (a) Dietrich-Buchecker, C. O.; Marnot, P. A.; Sauvage, J. P.; Kirchhoff, J. R.; McMillin, D. R. J. Chem. Soc., Chem. Commun. 1983, 513. (b) Cuttell, D. G.; Kuang, S. M.; Fanwick, P. E.; McMillin, D. R.; Walton, R. A. J. Am. Chem. Soc. 2002, 124, 6. (c) Smith, C. S.; Mann, K. R. J. Am. Chem. Soc. 2012, 134, 8786. (d) Ruthkosky, M.; Kelly, C. A.; Castellano, F. N.; Meyer, G. J. Coord. Chem. Rev. 1998, 171, 309.

(7) (a) Otto, S.; Grabolle, M.; Förster, C.; Kreitner, C.; ReschGenger, U.; Heinze, K. Angew. Chem., Int. Ed. 2015, 54, 11572. (b) Higgins, R. F.; Fatur, S. M.; Shepard, S. G.; Stevenson, S. M.; Boston, D. J.; Ferreira, E. M.; Damrauer, N. H.; Rappe, A. K.; Shores, M. P. J. Am. Chem. Soc. 2016, 138, 5451. (c) McDaniel, A. M.; Tseng, H. W.; Hill, E. A.; Damrauer, N. H.; Rappe, A. K.; Shores, M. P. Inorg. 
Chem. 2013, 52, 1368. (d) McDaniel, A. M.; Tseng, H. W.; Damrauer, N. H.; Shores, M. P. Inorg. Chem. 2010, 49, 7981.

(8) (a) Monat, J. E.; McCusker, J. K. J. Am. Chem. Soc. 2000, 122, 4092. (b) Juban, E. A.; Smeigh, A. L.; Monat, J. E.; McCusker, J. K. Coord. Chem. Rev. 2006, 250, 1783. (c) McCusker, J. K.; Walda, K. N.; Dunn, R. C.; Simon, J. D.; Magde, D.; Hendrickson, D. N. J. Am. Chem. Soc. 1993, 115, 298. (d) Aubock, G.; Chergui, M. Nat. Chem. 2015, 7, 629. (e) Canton, S. E.; Zhang, X. Y.; Lawson Daku, L. M.; Smeigh, A. L.; Zhang, J. X.; Liu, Y. Z.; Wallentin, C. J.; Attenkofer, K.; Jennings, G.; Kurtz, C. A.; Gosztola, D.; Warnmark, K.; Hauser, A.; Sundström, V. J. Phys. Chem. C 2014, 118, 4536. (f) Hauser, A.; Reber, C. Struct. Bonding (Berlin, Ger.) 2016, 172, 291. (g) Cannizzo, A.; Milne, C. J.; Consani, C.; Gawelda, W.; Bressler, C.; van Mourik, F.; Chergui, M. Coord. Chem. Rev. 2010, 254, 2677.

(9) (a) Liu, Y. Z.; Harlang, T.; Canton, S. E.; Chabera, P.; SuarezAlcantara, K.; Fleckhaus, A.; Vithanage, D. A.; Goransson, E.; Corani, A.; Lomoth, R.; Sundström, V.; Wärnmark, K. Chem. Commun. 2013, 49, 6412. (b) Jamula, L. L.; Brown, A. M.; Guo, D.; McCusker, J. K. Inorg. Chem. 2014, 53, 15. (c) Liu, Y. Z.; Persson, P.; Sundström, V.; Warnmark, K. Acc. Chem. Res. 2016, 49, 1477. (d) Fredin, L. A.; Papai, M.; Rozsalyi, E.; Vanko, G.; Wärnmark, K.; Sundström, V.; Persson, P. J. Phys. Chem. Lett. 2014, 5, 2066.

(10) (a) Duchanois, T.; Etienne, T.; Cebrian, C.; Liu, L.; Monari, A.; Beley, M.; Assfeld, X.; Haacke, S.; Gros, P. C. Eur. J. Inorg. Chem. 2015, 2015, 2469. (b) Harlang, T. C. B.; Liu, Y. Z.; Gordivska, O.; Fredin, L. A.; Ponseca, C. S.; Huang, P.; Chabera, P.; Kjaer, K. S.; Mateos, H.; Uhlig, J.; Lomoth, R.; Wallenberg, R.; Styring, S.; Persson, P.; Sundström, V.; Wärnmark, K. Nat. Chem. 2015, 7, 883. (c) Liu, Y. Z.; Kjaer, K. S.; Fredin, L. A.; Chabera, P.; Harlang, T.; Canton, S. E.; Lidin, S.; Zhang, J. X.; Lomoth, R.; Bergquist, K. E.; Persson, P.; Wärnmark, K.; Sundström, V. Chem. - Eur. J. 2015, 21, 3628. (d) Liu, L.; Duchanois, T.; Etienne, T.; Monari, A.; Beley, M.; Assfeld, X.; Haacke, S.; Gros, P. C. Phys. Chem. Chem. Phys. 2016, 18, 12550.

(11) (a) Mann, K. R.; Gray, H. B.; Hammond, G. S. J. Am. Chem. Soc. 1977, 99, 306. (b) Sattler, W.; Ener, M. E.; Blakemore, J. D.; Rachford, A. A.; LaBeaume, P. J.; Thackeray, J. W.; Cameron, J. F.; Winkler, J. R.; Gray, H. B. J. Am. Chem. Soc. 2013, 135, 10614. (c) Sattler, W.; Henling, L. M.; Winkler, J. R.; Gray, H. B. J. Am. Chem. Soc. 2015, 137, 1198. (d) Kvapilova, H.; Sattler, W.; Sattler, A.; Sazanovich, I. V.; Clark, I. P.; Towrie, M.; Gray, H. B.; Zalis, S.; Vlcek, A. Inorg. Chem. 2015, 54, 8518.

(12) (a) Xie, X. L.; Simon, J. D. J. Phys. Chem. 1989, 93, 4401. (b) Shaw, L. E.; Langford, C. H. Inorg. Chem. 2000, 39, 541. (c) Stufkens, D. J. Coord. Chem. Rev. 1990, 104, 39. (d) Vlcek, A., Jr. Coord. Chem. Rev. 1998, 177, 219.

(13) Büldt, L. A.; Guo, X. W.; Prescimone, A.; Wenger, O. S. Angew. Chem., Int. Ed. 2016, 55, 11247.

(14) (a) Angelici, R. J.; Quick, M. H.; Kraus, G. A.; Plummer, D. T. Inorg. Chem. 1982, 21, 2178. (b) Plummer, D. T.; Angelici, R. J. Inorg. Chem. 1983, 22, 4063. (c) Winzenburg, M. L.; Kargol, J. A.; Angelici, R. J. J. Organomet. Chem. 1983, 249, 415. (d) Plummer, D. T.; Kraus, G. A.; Angelici, R. J. Inorg. Chem. 1983, 22, 3492. (e) Hahn, F. E.; Tamm, M. Angew. Chem., Int. Ed. Engl. 1991, 30, 203. (f) Hahn, F. E. Angew. Chem., Int. Ed. Engl. 1993, 32, 650. (g) Naik, A.; Maji, T.; Reiser, O. Chem. Commun. 2010, 46, 4475. (h) Naik, A.; Meina, L.; Zabel, M.; Reiser, O. Chem. - Eur. J. 2010, 16, 1624. (i) Vicenzi, D.; Sgarbossa, P.; Biffis, A.; Tubaro, C.; Basato, M.; Michelin, R. A.; Lanza, A.; Nestola, F.; Bogialli, S.; Pastore, P.; Venzo, A. Organometallics 2013, 32, 7153. (j) Monti, F.; Baschieri, A.; Matteucci, E.; Mazzanti, A.; Sambri, L.; Barbieri, A.; Armaroli, N. Faraday Discuss. 2015, 185, 233. (k) Bagal, D. B.; Kachkovskyi, G.; Knorn, M.; Rawner, T.; Bhanage, B. M.; Reiser, O. Angew. Chem., Int. Ed. 2015, 54, 6999. (1) Knorn, M.; Rawner, T.; Czerwieniec, R.; Reiser, O. ACS Catal. 2015, 5, 5186. (m) Knorn, M.; Lutsker, E.; Reiser, O. Organometallics 2015, 34, 4515 .

(15) (a) Carpenter, A. E.; Margulieux, G. W.; Millard, M. D.; Moore, C. E.; Weidemann, N.; Rheingold, A. L.; Figueroa, J. S. Angew. Chem., Int. Ed. 2012, 51, 9412. (b) Fox, B. J.; Millard, M. D.; DiPasquale, A. G.; Rheingold, A. L.; Figueroa, J. S. Angew. Chem., Int. Ed. 2009, 48,
3473. (c) Margulieux, G. W.; Weidemann, N.; Lacy, D. C.; Moore, C. E.; Rheingold, A. L.; Figueroa, J. S. J. Am. Chem. Soc. 2010, 132, 5033. (d) Ditri, T. B.; Fox, B. J.; Moore, C. E.; Rheingold, A. L.; Figueroa, J. S. Inorg. Chem. 2009, 48, 8362. (e) Emerich, B. M.; Moore, C. E.; Fox, B. J.; Rheingold, A. L.; Figueroa, J. S. Organometallics 2011, 30, 2598. (f) Stewart, M. A.; Moore, C. E.; Ditri, T. B.; Labios, L. A.; Rheingold, A. L.; Figueroa, J. S. Chem. Commun. 2011, 47, 406. (g) Fox, B. J.; Sun, Q. Y.; DiPasquale, A. G.; Fox, A. R.; Rheingold, A. L.; Figueroa, J. S. Inorg. Chem. 2008, 47, 9010.

(16) (a) Schaper, F.; Wrobel, O.; Schworer, R.; Brintzinger, H. H. Organometallics 2004, 23, 3552. (b) Anderson, K. A.; Scott, B.; Wherland, S.; Willett, R. D. Acta Crystallogr., Sect. C: Cryst. Struct. Commun. 1991, 47, 2337. (c) Ljungström, E.; et al. Acta Chem. Scand. 1978, 32a, 47.

(17) (a) Farrell, I. R.; Matousek, P.; Towrie, M.; Parker, A. W.; Grills, D. C.; George, M. W.; Vlcek, A. Inorg. Chem. 2002, 41, 4318. (b) Maskova, E.; Vlcek, A. Inorg. Chim. Acta 1996, 242, 17.

(18) (a) Bullock, J. P.; Mann, K. R. Inorg. Chem. 1989, 28, 4006. (b) Mialki, W. S.; Wigley, D. E.; Wood, T. E.; Walton, R. A. Inorg. Chem. 1982, 21, 480. (c) Treichel, P. M.; Firsich, D. W.; Essenmacher, G. P. Inorg. Chem. 1979, 18, 2405. (d) Treichel, P. M.; Essenmacher, G. J. Inorg. Chem. 1976, 15, 146.

(19) Bohling, D. A.; Evans, J. F.; Mann, K. R. Inorg. Chem. 1982, 21, 3546.

(20) Mann, K. R.; Cimolino, M.; Geoffroy, G. L.; Hammond, G. S.; Orio, A. A.; Albertin, G.; Gray, H. B. Inorg. Chim. Acta 1976, 16, 97.

(21) In the case of $\mathrm{Cr}\left(\mathrm{CN}^{\mathrm{tBu}} \mathrm{Ar}_{3} \mathrm{NC}\right)_{3}$ (Figure 3a), the luminescence band position is such that an artefact caused by the spectrofluorimeter at $645 \mathrm{~nm}$ suggests a double band structure, but without this artefact, the emission band shapes of $\mathrm{Cr}\left(\mathrm{CN}^{\mathrm{tBu}} \mathrm{Ar}_{3} \mathrm{NC}\right)_{3}$ and $\mathrm{Mo}\left(\mathrm{CNAr}_{3} \mathrm{NC}\right)_{3}$ would be similar.

(22) (a) Heath, G. A.; Yellowlees, L. J.; Braterman, P. S. J. Chem. Soc., Chem. Commun. 1981, 287. (b) Yoshimura, A.; Hoffman, M. Z.; Sun, H. J. Photochem. Photobiol., A 1993, 70, 29. (c) Müller, P.; Brettel, K. Photochem. Photobiol. Sci. 2012, 11, 632.

(23) Sun, Q. C.; Mosquera-Vazquez, S.; Lawson Daku, L. M.; Guenee, L.; Goodwin, H. A.; Vauthey, E.; Hauser, A. J. Am. Chem. Soc. 2013, 135, 13660.

(24) Lees, A. J. Chem. Rev. 1987, 87, 711.

(25) (a) Iuchi, K.; Asada, S.; Sugimori, A. Chem. Lett. 1974, 3, 801. (b) Iuchi, K.; Asada, S.; Kinugasa, T.; Kanamori, K.; Sugimori, A. Bull. Chem. Soc. Jpn. 1976, 49, 577. (c) Fu, W. F.; van Eldik, R. Inorg. Chim. Acta 1996, 251, 341.

(26) (a) Bensasson, R.; Land, E. J. Trans. Faraday Soc. 1971, 67, 1904. (b) Dempster, D. N.; Morrow, T.; Quinn, M. F. J. Photochem. 1973, 2, 329. (c) Balazs, G. C.; del Guerzo, A.; Schmehl, R. H. Photochem. Photobiol. Sci. 2005, 4, 89. (d) Schoonover, J. R.; Dattelbaum, D. M.; Malko, A.; Klimov, V. I.; Meyer, T. J.; StyersBarnett, D. J.; Gannon, E. Z.; Granger, J. C.; Aldridge, W. S.; Papanikolas, J. M. J. Phys. Chem. A 2005, 109, 2472.

(27) Montalti, M.; Credi, A.; Prodi, L.; Gandolfi, M. T. Handbook of Photochemistry; CRC Taylor \& Francis: Boca Raton, FL, 2006.

(28) (a) Parker, C. A.; Hatchard, C. G. Proc. Chem. Soc., London 1962, 386. (b) Islangulov, R. R.; Kozlov, D. V.; Castellano, F. N. Chem. Commun. 2005, 3776. (c) Singh-Rachford, T. N.; Haefele, A.; Ziessel, R.; Castellano, F. N. J. Am. Chem. Soc. 2008, 130, 16164. (d) SinghRachford, T. N.; Castellano, F. N. Coord. Chem. Rev. 2010, 254, 2560. (e) Zhao, J. Z.; Wu, W. H.; Sun, J. F.; Guo, S. Chem. Soc. Rev. 2013, 42, 5323. (f) Ji, S. M.; Guo, H. M.; Wu, W. T.; Wu, W. H.; Zhao, J. Z. Angew. Chem., Int. Ed. 2011, 50, 8283. (g) Schmidt, T. W.; Castellano, F. N. J. Phys. Chem. Lett. 2014, 5, 4062. (h) Askes, S. H. C.; Bahreman, A.; Bonnet, S. Angew. Chem., Int. Ed. 2014, 53, 1029.

(29) (a) Haefele, A.; Blumhoff, J.; Khnayzer, R. S.; Castellano, F. N. J. Phys. Chem. Lett. 2012, 3, 299. (b) Pollnau, M.; Gamelin, D. R.; Lüthi, S. R.; Güdel, H. U.; Hehlen, M. P. Phys. Rev. B: Condens. Matter Mater. Phys. 2000, 61, 3337.

(30) (a) Carlotti, B.; Cesaretti, A.; Gentili, P. L.; Marrocchi, A.; Elisei, F.; Spalletti, A. Phys. Chem. Chem. Phys. 2016, 18, 23389. (b) Sepiol, J. 
J. Lumin. 1986, 36, 115. (c) Jurczok, M.; Plaza, P.; Martin, M. M.; Meyer, Y. H.; Rettig, W. Chem. Phys. 2000, 253, 339.

(31) Islangulov, R. R.; Castellano, F. N. Angew. Chem., Int. Ed. 2006, $45,5957$.

(32) (a) Zhang, W. K.; Alonso-Mori, R.; Bergmann, U.; Bressler, C.; Chollet, M.; Galler, A.; Gawelda, W.; Hadt, R. G.; Hartsock, R. W.; Kroll, T.; Kjaer, K. S.; Kubicek, K.; Lemke, H. T.; Liang, H. Y. W.; Meyer, D. A.; Nielsen, M. M.; Purser, C.; Robinson, J. S.; Solomon, E. I.; Sun, Z.; Sokaras, D.; van Driel, T. B.; Vanko, G.; Weng, T. C.; Zhu, D. L.; Gaffney, K. J. Nature 2014, 509, 345. (b) Bressler, C.; Milne, C.; Pham, V. T.; ElNahhas, A.; van der Veen, R. M.; Gawelda, W.; Johnson, S.; Beaud, P.; Grolimund, D.; Kaiser, M.; Borca, C. N.; Ingold, G.; Abela, R.; Chergui, M. Science 2009, 323, 489.

(33) Cannizzo, A.; Blanco-Rodriguez, A. M.; El Nahhas, A.; Sebera, J.; Zalis, S.; Vlcek, A., Jr.; Chergui, M. J. Am. Chem. Soc. 2008, 130, 8967. 